\title{
INNOVATIONS IN ARTICLES THREE AND FOUR OF THE UNIFORM COMMERCIAL CODE
}

\author{
Richard Cosway*
}

This article proposes to apprise the reader of the more significant innovations to be found in Articles 3 (Commercial Paper) and 4 (Bank Deposits and Collections) of the Uniform Commercial Code. ${ }^{1}$ The plan followed is simple. First, an attempt will be made to state briefly some of the problems existing under the present Negotiable Instruments Law which warrant recodification. Second, an attempt will be made to indicate how the proposed Articles of the Uniform Commercial Code will solve those problems. Third, and finally, attention will be called to the changes to be found in the proposed Code which promise to be the most significant. Unfortunately, time and space do not permit a complete analysis of all the modifications to be found, since the changes in wording are legion.

Concerning a need for a change, no serious contention can be made that the present situation is anything like the hotch-potch existing prior to the enactment of the Uniform Negotiable Instruments Law. The absolute need for uniform legislation was so clear that all of the states, territories, and possessions of the United States, including the District of Columbia, have adopted the Uniform Negotiable Instruments Law. ${ }^{2}$ In general, that law has been a workable statute, producing an orderly solution to the problems arising in the field of bills and notes.

Inertia compels the mind to tend to want to stick with an old statute, uniformly adopted, which has become familiar, rather than to scrap the old in favor of a new, untried and unfamiliar piece of legislation. It would seem that strong and compelling reasons would have to be adduced before one would be motivated to support such a change. Are there any such reasons?

The concept of a commercial code, correlating laws respecting sales, negotiable instruments, bank collections, documents of title, security transactions, and other related commercial problems is an obvious step forward. Today, the statutes in these fields are not well integrated. Difficult problems of construction arise when interpretation of two uncoordinated statutes is involved. ${ }^{3}$ Divergent approaches exist among the various acts. Under the Negotiable Instruments Law, for example, paper which is bearer paper on its face remains negotiable by delivery, though

- A.B. I939, Denison University; LL.B. 1942, University of Cincinnati. Assistant Professor of Law, University of Cincinnati.

${ }^{1}$ Citations appearing in this article are based on the Spring, r950 Proposed Final Draft of the Uniform Commercial Code, for Article 3, and on the September, 1950 revisions of the Uniform Commercial Code for Article 4 .

25 Uniform LAws ANNOTATED 6 (Supp. I950).

${ }^{3}$ See, e.g., Farm \& Home Savings \& Loan Ass'n of Missouri v. Stubbs, 23 I Mo. App. 87, 98 S. W.2d 320 (1936), involving the Negotiable Instruments Law and the Bank Collection Code. 
specially indorsed; $;^{4}$ while paper payable to order on its face, but indorsed in blank, may subsequently be controlled by a later special indorsement. ${ }^{5}$ Under the Uniform Sales Act, ${ }^{6}$ the Uniform Bills of Lading Act, ${ }^{7}$ and the Uniform Warehouse Receipts Act, ${ }^{8}$ no distinction is made between documents running to bearer on their face and documents running to order and indorsed in blank. In both instances, a special indorsement may control the method by which the paper is thereafter to be negotiated.

There is no inherent reason why different treatment in this regard should be given documents of title from that accorded money instruments, so the diversity in approach can only be explained by the historical accident that errors made in the first-written Negotiable Instruments Law were rectified in the later acts.

A comparison of Section 7-50r of the Code with Section 3-204 will show that a uniform approach has been taken to both types of instruments. In both, the last indorsement controls, whether the paper is payable to bearer or payable to order on its face. This, of course, changes the common law rule, ${ }^{9}$ and the rule of Negotiable Instruments Law Section 40. The advantage gained is harmony among the various types of documents. In addition, the rule adopted seems to accord with business custom in treating in the same fashion paper which has been rendered bearer paper by a blank indorsement as that which is bearer paper on its face. A policy argument could be made that to permit paper which is issued as bearer paper to be converted into order paper by a special indorsement is to modify the contract made by the maker or drawer, and thereby subject him to the added risk of forged indorsement which he didn't contemplate. ${ }^{10}$ The desirability of permitting an owner of paper to control its negotiation and thereby preserve his property rights in the paper seems to outweigh that policy. At any event, the need for similarity of treatment in the various acts is patent and has been met.11

A second troublesome factor in the Negotiable Instruments Law is that statute's narrow requirement that, "An instrument to be negotiable must conform to the following requirements."12 While it has been ably argued that this section does not forestall development of other forms of negotiable instruments, ${ }^{13}$ the effect of this restrictive language has been that, on occasion, the meaning of words has been strained in order to jam into the limits of the Negotiable Instruments Law bonds which contained provisions violating the plain meaning of that law. ${ }^{14}$ The courts were faced with a dilemma in many cases: either adhere to the letter of the law,

- Negotiable Instruments Law \$40.

\$\$28 and 29.

- Negotiable Inștruments Law $\$ 9(5)$.

${ }_{7} \$ 28$ and 29 . $\quad 8 \$ 37$ and $3^{8 .}$

- Smith v. Clarke, I Esp. I80, I70 Eng. Rep. 320 (N. P. I794); Mitchell v. Fuller, I5 Pa. 268, 53 Am. Dec. 594 (I850).

10 Brannan, Negortable Instruments Law Annotated 630 (Beutel, 7th ed. 1948); Palmer, Negotiable Instruments Under the Uniform Commercial Code, 48 Mrcr. L. REv. 255, 275 (1950).

${ }^{11}$ It will be apparent that the analysis of $\$ \$ 9(5)$ and 40 of the Negotiable Instruments Law here made is extremely simplified. Other interpretations of these two sections are available.

${ }^{22}$ Negotiable Instrumients Law \$I.

${ }^{23}$ Beutel, Negotiability by Contract, 28 ILL. L. Rev, 205 (1933).

i4 See Britton, Brils aid Notes \$I7 (1943). 
thereby rendering non-negotiable many widely-held bonds, or stretch legal principles to permit declaration of negotiability of some doubtful instruments. ${ }^{15}$

The basic difficulty is that the large investment-securities market has developed for the most part since 1896 , when the Negotiable Instruments Law was written. Though bonds were squeezed into the coverage of the act by court decision, as the illustrations just cited show, and though the Negotiable Instruments Law itself makes one reference to securities, ${ }^{16}$ it seems doubtful whether a development which occurred after the statute was written should be held to be covered by the statute. Sensing this anachronism, the drafters of the Uniform Commercial Code have withdrawn investment securities into a separate Article, where they are treated differently from short-term obligations. ${ }^{17}$

There have been other developments since 1896 , rendering inappropriate certain requirements imposed by the Negotiable Instruments Law. Protest of an instrument drawn in New Jersey, payable in New York (or even Illinois or some more remote state), while appropriate in times when travel and communication were relatively slow and difficult, does not seem essential to modern practice. Some states have amended the Negotiable Instruments Law to change the definition of "foreign bills," so as to make protest unnecessary for instruments drawn and payable within the United States. ${ }^{18}$ Accordingly, the Code ${ }^{10}$ makes protest mandatory only in case of drafts which on their face appear to be drawn or payable outside of the states and territories of the United States and the District of Columbia. Acceptance for honor, which likewise is obsolete, is abolished by the Code. ${ }^{20}$

Indeed, certain defects in the Negotiable Instruments Law existed at the outset. Mention has already been made of the difficulties posed in construing Negotiable Instruments Law Sections $9(5)$ and 40. Other illustrations come readily to hand, but only one will be specifically mentioned at this point. By virtue of the operation of Negotiable Instruments Law Sections $36(3), 37$ and 47 , an indorsement from A, "To B in trust for C," has been held to terminate negotiability with the result that $B$ isn't a holder in due course. ${ }^{21}$ There are any number of sound reasons why an indorsee might want to take through an indorsement creating a trust for the benefit of a third person. An honest trustee might desire to hold all trust documents in that fashion, and that method of holding does not indicate that the indorsee gave no

\footnotetext{
${ }^{15}$ Two illustrations must suffice. In Enoch v. Brandon, 249 N. Y. 263,164 N. E. 45,46 (1928), bonds were declared negotiable, even though they contained a recitation of a securing mortgage "to which reference is hereby made for a description of the property mortgaged and pledged, the nature and extent of the security, the rights of the holders of the bonds with respect thereto, the manner in which notice may be given to such holders, and the terms and conditions upon which said bonds are issued and secured." In Hibbs v. Browa, r90 N. Y. 167, 82 N. E. I108 (1907), a bond was held negotiable, though expressly payable only out of the assets of a partnership which had a corporate-sounding name.

${ }^{10}$ Negottable INSTRuments Law $\$ 65$ excludes from the warranty coverage of the law those persons "negotiating public or corporation securities."

${ }_{17} \$ 3-\mathrm{rO} 3$ of the Code provides: "This Article does not govern money, documents of title or investment securities."

${ }^{18}$ Cal. Crv. Code $\$ 3210$ (1947); Note, 2I So. Calif. L. Rev. 173 (1948).

19 \$3-5or.

20 \$3-4ro.

${ }^{21}$ Gulbranson-Dickinson Co. v. Hopkins, 170 Wis. 326 , 175 N. W. 93 (1919).
} 
value for the instrument ${ }^{22}$ or that the taker isn't a due course holder. It is submitted, therefore, that Gulbranson-Dickinson Co.v. Hopkins ${ }^{23}$ produces undesirable results and is wrong in policy; therefore, the Negotiable Instruments Law, which either required or certainly made easy that result, should be changed. The Code ${ }^{24}$ will change the result of the Gulbranson-Dickinson case. ${ }^{25}$

Other illustrations of erroneous concepts which have developed under the present statute will be adverted to in the discussion of significant developments resulting from the adoption of the Code. Their repetition here is deemed not necessary to establish the argument that there are defects in the Negotiable Instruments Law. However, one defect of prime importance in demonstrating the need for a recodification is the lack of uniformity in the Uniform Negotiable Instruments Law. About 300 amendments have been made by various states to the law. ${ }^{26}$ Honesty requires an admission that this statistic overstates the argument, since most of the changes haven't been of great significance, but the fact remains that even a cursory examination of the Negotiable Instruments Law as annotated by the Editors of Uniform Laws Annotated ${ }^{27}$ will reveal some deviation in $\mathrm{II} 6$ of the Ig8 sections of the law.

More significant, though, is the fact that courts have differed in the interpretation of sections uniformly worded. ${ }^{28}$ A compilation of the evidence to support this conclusion would be nothing other than a casebook for use in a course in Bills and Notes. Take but one illustration-the available interpretations of the effect of adding the words, "I assign the within note," before a signature on the back of an instrument, or the words, "I assign my interest in the within note," in the same position. Authority can be found that ( $I$ ) this is a qualified indorsement, ${ }^{29}(2)$ this is a blank or special indorsement, ${ }^{30}$ (3) this isn't an indorsement at all, ${ }^{31}$ or (4) the words aren't a commercial indorsement so as to constitute a taker a due course holder, yet the writer of those words may be liable as an indorser. ${ }^{32}$ To terminate this diversity, the Code says:

Words of assignment, condition, waiver, guaranty, limitation or disclaimer of liability and the like accompanying an indorsement do not affect its sufficiency for negotiation. ${ }^{33}$

${ }^{22}$ Hook v. Pratt, 78 N. Y. $37 x, 34$ Am. Riep. 539 (1879).

${ }^{23}$ Stipra note 21 .

${ }^{25}$ \$3-206, Comment 3. Professor Athol Lee Taylor's argument in Indorsements for Collection:Under the Negotiable Instruments Law and the Uniform Commercial Code, 1950 WASH. U. L. Q. 55, 7o et seq. ( 1950 ) to the effect that the rule of the Gulbranson-Dickinson case has not been changed may have overlooked the possibility that value given either by the trustee or the beneficiary is sufficient to constitute value within the meaning of Negottable INSTRUMents LaW \$52. Stokes v. Riley, x21 Ill. I66, I7I II N. E. 877 (I887) shows this.

${ }^{20}$ James M. Ogden, The Law of Negotiable Instruments $\$ 7$ (5th ed. 1947). .

375 Uniform Laws ANNotated (I943).

${ }^{28}$ Beutel, Problems of Interpretation Under the Negotiable lnstruments Law, 27 NEB. LAw REv. 485 (1948); Leary, Some Clarifications in the Law of Commercial Paper 'Under the Proposed Uniform Commercial Code, 97 U. of PA. L. Rev. 354 (1949).

${ }^{90}$ Marion National Bank v. Harden, 83 W. Va. Ir9, 97 S. E. 600 (1918); Evans v. Freeman, 142 N. C. 61,54 S. E. 847 (1906).

${ }^{30}$ Fay v. Witte, 262 N. Y. 215 , I86 N. E. 678 (1933); Copeland v. Burk, 59 Oklahoma 219, 158 Pac. II62 (I916).

${ }^{31}$ Aniba v. Yeomans, 39 Mich. 17I (1878); Gale v. Mayhew, r6r Mich. 96, I25 N. W. 78x (19xo).

${ }^{32}$ Carius v. Ohio Contract Purchase Co., 30 Ohio App. 57, I6 64 N. E. 234 (1928), criticized in 3 U. of Cin. L. Rev. 225 (1929).

${ }^{33} \$ 3-202(4)$. 
Here again, example can be added to example, but it will be assumed that illustrations can be selected from materials later in this article to bolster the argument presented.

At this point, attention should be called to the second problem concerned in adoption of a recodification of the law governing bills and notes, namely, whether there is any reason to believe that the suggested statute can solve the existing problems without creating new difficulties. Although the answer is speculative, there are factors which will make possible a greater degree of uniformity (if uniformity comes in degrees) under the new Code than exists under existing statutes. To predict that the Code will be a panacea would be unduly optimistic, but an espousal of the Code requires some evidence that improvements will follow its adoption. These suggestions are offered.

First of all, experience is a good teacher, and the current crop of statute drafters has had the advantage of 54 years of dealing under the Negotiable Instruments Law. Flaws in that law have been ferreted out, so the new Code can be written with an eye toward correcting previous mistakes. Throughout the comments to the various sections of the Code, evidence abounds that the writers are familiar with existing case law, and that the legislation is written with that case law in mind. Not infrequently, the Code appears ridiculous unless the present status of the law is kept in mind. For example, observe the following provisions of the Code with respect to want or failure of consideration:

Unless he has the rights of a holder in due course any person takes the instrument subject to: ... (b) all defenses of any party which would be available in an action on a simple contract; and (c) the defenses of want or failure of consideration, non-performance of any condition precedent, non-delivery, or delivery for a special purpose. . . . ${ }^{34}$

Clause (b) appears sufficiently broad to include the defenses of want or failure of consideration, and clause (c) consequently seems redundant. Nonetheless, in Section 3-408, the Code again declares:

Want or failure of consideration is a defense as against any person not having the rights of a holder in due course....

The reader who challenges such a comprehensive coverage of so obvious a point is reminded of the fate of Negotiable Instruments Law Section 28, which states:

Absence or failure of consideration is matter of defense against any person not a holder in due course....

By weight of authority, absence and failure of consideration are thereby sufficiently clearly designated as defenses, so that the defendant would have the burden of establishing both..$^{35}$ However, many courts have refused to recognize this effect of the Negotiable Instruments Law and have continued to abide by the common law principle that where the issue is want of consideration, the burden to prove con-

34 \$3-306.

38 Britton, Bills and Notes 405 (1943); Brannan, Negottable Intruments Law Annotated 485 , $\$ 24$ (Beutel, 7th. ed. I948); I Williston, Contracts $\$ 108$ (Rev. ed. I936). 
sideration is on the holder. ${ }^{36}$ The Code's specific provision, coupled with the provisions on burden of establishing defenses contained in Section $3-307,{ }^{37}$ will require all courts to treat both want of consideration and failure of consideration as matters for the defendant to prove. No suggestion is intended that these desired results will be automatic. Courts may decide cases, and lawyers may argue cases on the basis of statutes long since repealed, but the chances are that such errors will be minimized once the provisions of the Code are comprehended.

To increase this protection against following traditional approaches, the Code is couched in new words. The drafters have elected not to put the wine of their new learning in old bottles. Where formerly appeared the phrase, "bill of exchange," now appears the word "draft."38 This substitution was probably only a modernizing venture, not intended to produce legal consequences; however, other changes in wording will vitiate present decisions. Negotiable Instruments Law Section 9(3) requires an instrument to be payable at a "fixed or determinable future time." The counterpart in the Code is Section $3-\mathrm{IO}_{4}(\mathrm{I})(\mathrm{c})$, which requires a "definite time." Technically, cases construing the Negotiable Instruments Law's requirement cannot be used to construe the new section, the interpretation of which must be based solely on the accompanying comments.

These comments are a third reason why uniformity may be anticipated if the Code is adopted, since they are a means of knowing the vicariously acquired "legislative intent."39 The comments are extremely beneficial, almost without exception. There are three such comments, however, which seem to contain some danger spots, and attention is invited to them:

(I) In Section 3-307(3) the Code provides:

After evidence of a defense has been introduced a person claiming the rights of a holder in due course has the burden of establishing that he or some person under whom he claims is in all respects ${ }^{40}$ a holder in due course.

The comment to this section indicates that, "Nothing in this section is intended to say that the plaintiff must necessarily prove that he is a holder in due course. . .."41 It is submitted that the quoted section does just that, and that the comment seeks to interpret the section contrary to the plain meaning of the words used. The Code and comment are as misleading as the instruction of the trial judge held to be error in Beacon Trust Co. v. Ryder. ${ }^{42}$ A plaintiff isn't bound to prove himself a due

${ }^{36}$ In re Kennedy's Estate, 82 Ohio App. 359, 80 N. E.2d 810 (1948), noted 18 U. of Cis. L. Rev. 219 (1949) is a recent example.

${ }_{37}$ "... . When signatures are admitted or established, production of the instrument entitles a holder to recover on it unless the defendant establishes a defense." A definition of burden of establishing appears in $\$ \mathrm{I}-20 \mathrm{I}(8)$.

${ }^{39}$ The word "bill," does, however, appear on occasion, e.g., in Comment 4 to $\$ 3-502$.

${ }^{30} \S_{1-102}$ contains a specific directive to look to the Comments to determine legislative intent.

${ }^{60}$ This phrase, "in all respects," will, as explained in the Comment, require the holder to prove all of the elements of due course holding, thereby solving a problem over which opinions differ under the current statute. See Glendo State Bank v. Abbott, 30 Wyo. 98, 216 Pac. 700 (1923), for an analysis of the cases.

${ }^{41}$ \$3-307, Comment 3 .

4273 Mass. 573 , 174 N. E. 725 (1931). 
course holder until the defendant has established a defense, because until that defense has been established, the issue of due course holding is not apposite. ${ }^{43}$

(2) In Section 3-403(2), the Code says:

An authorized representative who signs his own name to an instrument is also personally obligated unless the instrument names the person represented and shows that the signature is made in a representative capacity. (Italics supplied.)

The word, "also," indicates that somebody else is liable, but in the event that the principal's name doesn't appear, only the agent is liable. ${ }^{44}$ It is suggested that the comment to this section does not sufficiently make clear when an agent may also be liable, the situation intended being the event that the principal's name appears along with the agent's name, without any indication that the latter signed for the former. ${ }^{45}$

(3) Comment 9 to Section $3-4{ }^{46}$ would seem to indicate that the warranties made by a transferor who does not indorse run to all subsequent holders of the instrument. ${ }^{47}$ Here again, the plain meaning of the section is to the contrary.

These minutiae should not be thought, however, to deny the basic thesis that the comments are an-excellent tool for interpretation of the statute, and they should be a vital factor in fostering uniform construction.

The fourth and final suggestion why the Code will stimulate uniformity is that the integrated codification of commercial law subjects will remove the need for stresses and distortions in attempting to correlate conflicting legislation and common law principles and thus will obviate many opportunities for divergent views. An illustration here is the difference in interpretation of the effect of Negotiable Instruments Law Sections IIg and I20 on the common law suretyship defenses. As a common law matter, a surety is discharged by a binding agreement of the creditor to extend the time of payment to the principal debtor without a reservation of rights against the surety. ${ }^{48}$ The Negotiable Instruments Law, written probably without regard to these suretyship defenses, has produced a difference of opinion as to whether this defense remains available to a surety who signs as the maker of a negotiable instrument. ${ }^{49}$ The Code treats the problem as follows:

The holder discharges any party to the instrument to the extent that without such party's consent the holder

"3 Obviously, the plaintiff's evidence on the question of due course holding must be introduced before the defendant's evidence on the question of the defense, but the approach here taken would be involved in phrasing instructions to a jury after all the evidence is in. The suggestion intended is that a court would err if it were to read, as its instructions to the jury, the statutory wording contained in $\$ 3-307(3)$.

" $\$ 3-401$ provides: "No person is liable on an instrument unless his signature appears thercon."

"Perhaps this argument is directed to the inclusion of the word "also," in the statute, rather than to the Comment explaining it. The writer is unable to explain why this word was added after the May, 1949 draft where it does not appear.

The relevant portion of this section is subparagraph (2): "Unless otherwise agreed any party who transfers an instrument for consideration so warrants to his transferce and if the transfer is by indorsement any subsequent holder if such person takes the instrument in good faith. . .."

17 The Comment says: "Subsection (2) changes the original Section 65 to extend the warrantics beyond the immediate transferee in all cases. The warranty runs with the instrument. ..."

${ }^{48}$ Restatement, Security $\$ 129$ (I941).

19 Britton, Bills and Notes \$301 (1943); Richards v. The Market Exchange Bank Co., 8I Ohio St. 348,90 N. E. 1000 (1910). 
(a) without express reservation of rights releases or agrees not to sue any person against whom the party has to the knowledge of the holder a right of recourse on the instrument, or agrees to suspend the right to enforce against such person the instrument or collateral. . . .50

By Section $3-415$ (5) an accommodation party who pays the instrument is given a right of recourse on the instrument. ${ }^{51}$

Under these two sections, a surety who appears as maker (or indorser, of course) of an instrument is discharged by an extension of time without reservation of rights. These sections are adroitly written, working a discharge of the person, not a discharge of the "instrument" as under Negotiable Instruments Law Section II9, and working this discharge without regard to the position of the surety on the instrument, if in fact he has a cause of action against another party which is interfered with by the extension.

Furthermore, parol evidence of the accommodation is available as against one not a due course holder, but a holder in due course takes free of any suretyship defenses unless he knows of the suretyship relationship. ${ }^{52}$ Finally, the suretyship right of subrogation is retained, entitling the surety to assert the payee's right on the instrument. ${ }^{\text {.3 }}$

In short, unlike the Negotiable Instruments Law, the Commercial Paper Article of the Code is written with a cognizance of problems arising in other fields of the law and incorporates principles from those other fields. This should be a factor in simplifying interpretation of the Code.

Of course, areas exist where uniformity will not be brought about. The section dealing with notes or acceptances payable at a bank $k^{54}$ is written with alternative provisions to adjust to differences in banking custom. In Section 3-I06(2), provision is made for divergent policies concerning stipulations obligating the payment of collection costs, attorney's fees, and the like. Since opinions differ as to the validity of these provisions, ${ }^{55}$ that difference of opinion will remain even after the Code is adopted. A similar leeway for difference of policy concerning cognovit notes is provided for by the Code. ${ }^{56}$ Further, the effect of the defense of infancy ${ }^{57}$ is left to the common law rule of a particular jurisdiction. In effect, infancy is retained as a real defense, as is true under the Negotiable Instruments Law. 58 However, Section 3-207 of the Code changes current law, in that while an infant indorser may disaffirm his contractual liability, he may not recover the instrument from a holder in due course. This terminates an existing anomaly by which an infant vendor of a chattel cannot recover the chattel from a bona fide purchaser, ${ }^{50}$ while

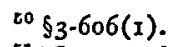

61 Thus another ambiguity in the Negotiable Instruments Law is removed. See Schmelze v. Transportation Inv. Corp., 94 N. E.2d 682 (IIl. App., 1950).

\footnotetext{
22 $\$ 3-415$.

a4 $\$ 3-122$.

$\varepsilon_{3} \$ 3-415(5), 3-60 \mathrm{r}(3)$.

ET ODGEN, NEGOTIABLE INSTRUMENTS $\$ 59$ (1947) shows the various approaches taken.

${ }^{20} \$ 3-112(2)$. ${ }^{87} \$ 3-305$.

${ }^{58}$ Murray v. Thompson, 136 Tenn. II 8 , x 88 S. W. 578 (x916).

$\because 0$ Unifora SALES AlcT \$24.
} 
the infant indorser of a negotiable instrument can retake that instrument even frum a holder in due course. ${ }^{60}$

So, in particular situations, there will be divergence in the law as it respects commercial paper, but in general, the suggestion is proffered that the Code will be an instrumentality for promoting uniformity. In short, the conclusion requested by the writer is that the case is made out for a change in existing codification and for the adoption of the Commercial Paper Article of the Code as the desirable change.

There remains the third general division of this article, a presentation of some of the paramount innovations to be brought about by adoption of Articles 3 and 4 of the Uniform Commercial Code. Illustrations in the preceding discussion will not be repeated, though many of the changes there analyzed will be of great importance. The underlying scheme in the following comments is merely a culling out of various sections deemed worthy of note or criticism. The order followed is, for the most part, the order of appearance in the Code itself.

In Section 3-I02, certain definitions appear, among which are these:

(d) An "order" is a clearly expressed direction to pay and must be more than a mere authorization or request. It must identify the drawee with reasonable certainty. It may be addressed to a single drawee or to drawees jointly or in the alternative but not in succession.

(e) A "promise" is a clearly expressed undertaking to pay and must be more than a mere acknowledgment of an obligation.

Obviously, the intended result of these sections is to compel a different result in cases holding instruments to be negotiable when only an implied in fact or implied in law promise can be found ${ }^{\text {B1 }}$ What, however, should be the effect of these sections on a fact situation similar to that posed in Didato v. Coniglio, ${ }^{62}$ where the defendant signed an instrument, "Pay to the order of $\mathrm{X}$," but addressed to no drawee? Certainly, the defendant cannot be held as the drawer of a bill of exchange (as was true under the Negotiable Instruments Law), but in the Didato case the defendant was held liable as the maker of a promissory note.

Exploring additional sections of the Code for an answer, one will come upon Section 3-IO4(2)(a), by which a draft is defined as an "order," and Section 3-I04(2)(d), by which a note is defined as a "promise." It would seem that the defendant cannot be held liable at all, therefore, and this conclusion is strengthened by the fact that Negotiable Instruments Law Section $10^{63}$ is omitted by the Code. ${ }^{04}$

${ }^{\circ 0}$ Murray v. Thompson, supra note 58 .

61 "I borrowed money from $S$, the sum of five hundred dollars (\$500.00) with 4 per cent interest. The borrowed money ought to be paid within four months from above date. [Signed] V." In Shemonia v. Verda, 24 Ohio App. 246,157 N. E. 717 (1927) a note containing those words was held to be an instrument for the unconditional payment of money only, within the meaning of a statute (OHIo GEN. CODE §rI334) authorizing a short form of pleading for such instruments. No question of negotiability was involved. A nice question of interpretation will be presented in Ohio, it would scem, as to whether the result of that case will be changed by codification of this section of the Code.

${ }^{62} 50$ Misc. 280, roo N. Y. Supp. 466 (Sup. Ct. 1906).

13 "The instrument need not follow the language of this act, but any terms are sufficient which clearly indicate an intention to conform to the requirements hereof."

of \$3-104, Comment 6. 
That section was relied on by the court in the Didato case.

However, Section 3-Irg(a) of the Code states:

Where there is doubt whether the instrument is a draft or a note the holder may treat it as either. A draft drawn on the drawer is effective as a note.

How can a situation be conceived wherein doubt can exist whether an instrument is a note or a draft, when a note is a clearly expressed promise and a draft is a clearly expressed order? This Section introduces an element of doubt into the picture, and if the Section be thought applicable to the hypothetical case, it would produce a result like that of the Didato case. At any event, a foreboding of difficult construction problems is created by the apparent conflict between Sections 3 -IIg(a) and 3-I02. Section 3-IIg(a) is a vestige from Section I7(5) of the present law, the repeal of which may be necessary.

This same Section of the Code, by authorizing joint or alternative drawees, has changed the law with respect to the latter category. The Negotiable Instruments Law precludes both alternative and successive drawees. ${ }^{65}$ The desirability of permitting alternative drawees has long been recognized, ${ }^{66}$ so the change seems desirable. By Section 3-504(2)(d) of the Code, presentment may be made to any one of the alternative drawees and, if so made, will be sufficient to hold those parties who are secondarily liable.

Section $3-\mathrm{IO}_{4}(2)$ (b) retains the essence of Negotiable Instruments Law Section 185, defining a check as a draft drawn on a bank, payable on demand. The Code also recognizes the validity of antedated and postdated instruments, ${ }^{67}$ so a postdated "check" is still possible under the Code. Presumably, a postdated check will be dealt with as a check, even though not technically payable on demand; consequently, the time for presentment specified for checks in Section 3-503 will apply to postdated checks. A similar problem is posed under the Negotiable Instruments Law, and the answer suggested is that reached by the courts under that statute. ${ }^{68}$

Greater difficulty may be encountered in dealing with two sections of the Code concerning negotiability of instruments secured by reservation of title. Section 3-I04(3) states:

A writing which purports to create or reserve security rights does not fall within this Article, even though it also contains a promise to pay money.

Then, Section 3-I05(I)(d) announces:

A promise or order otherwise unconditional is not made conditional by the fact that the instrument ... states that it is secured, whether by mortgage, reservation of title or otherwise.

How would the following instrument fit into these sections?

On or before the first day of October, I953, for value received, the undersigned

ot Negotiable Instruments Law $\S \mathbf{r} 28$.

${ }^{\circ 0}$ Ogden, Negotiable Instruments $\$ 56$ (1947).

of \$3-315, 3-304(5) (a).

os Philadelphia Life Ins. Co. v. Hayworth, 296 Fed. 339 (4th Cir. 1924). 
promise to pay to Arkansas Valley Breeding Co. or order six hundred dollars, negotiable and payable at Little Rock, Ark.; it being given for Percheron stallion named Robert, No. 4068r, and this day delivered to the maker of this note, with the understanding and agreement between the maker of this note and the Arkansas Valley Breeding Co. that the above described property is and shall remain in said Arkansas Valley Breeding Co., with full power of disposition without notice, in such manner as he may see fit, until paid for. . . . ${ }^{69}$

The seller's reservation of title does not condition the instrument under Section $3-105(\mathrm{I})(\mathrm{d}) ;^{70}$ however, some doubt seems to exist whether this same note might not come within the meaning of Section 3-I04(3), since it reserves a security. A reference to the comment, though, warrants the conclusion that Section 3-104(3) is intended to remove from that Article instruments which are conditional sales, disguised as promissory notes. ${ }^{71}$ No definite guide exists to determine the precise provisions which may safely be included in a negotiable instrument. ${ }^{72}$

The entire problem of transferability of conditional sales contracts is difficult. Perhaps there are policy arguments why those instruments should not be negotiable; ${ }^{73}$ therefore, the codifiers acted wisely in rejecting the Abingdon decision, but difficult problems of construction may be expected in this area of the Code. The test in each case must be whether the instrument is a conditional sales contract, disguised as a note and therefore not within the Article, or a note, carrying with it a protective reservation of title as security, and hence negotiable. ${ }^{\mathbf{7 4}}$

An innovation more readily explained is contained in this same Section, dealing with conditional paper. The Code says:

A promise or order otherwise unconditional is not made conditional by the fact that the instrument . . . is limited to payment out of the entire assets of a partnership, unincorporated association, trust or estate by or on behalf of which the instrument is issued..$^{75}$

This is new, and it will have the effect of making unnecessary the circumlocution demonstrated in Hibbs $v$. Brown, ${ }^{76}$ to which reference has already been made. ${ }^{77}$

${ }^{\circ 0}$ Welch v. Owenby, 73 Okla. 212, I75 Pac. 746 (1918), involved such a notc.

${ }^{70}$ For discussion of cases under the existing statute, see Britton, BiLLS AND NoTEs $\$ 14$ (1943).

${ }^{71}$ The Comment (Paragraph 3) cites as an example of the type of instrument covered the paper involved in Abingdon Bank \& Trust Co. v. Shipplett-Moloney Co., 316 Ill. App. 79, 43 N. E.2d 857 (1942). That paper was a conditional sales contract, embodying a promissory note. Clearly, that would no longer be negotiable.

72 The Comment indicates that a negotiable instrument is a courier without luggage. That phrase didn't mean anything when it was used in 1846 in Overton v. Tyler, 3 Pa. St. 346,45 Am. Dec. 645 $(1846)$, and its repetition in the Comment doesn't increase its significance. It would secm that some specific requirements must be set forth, and that the general concept of luggageless paper does not come to grips with any legal problem.

${ }_{73}$ Commercial Credit Corp. v. Orange County Machine Works, 34 Cal. 2d 766, 214 P.2d 819 (1950), illustrates the difficulty. And see Note, 57 Y ALE L. J. 1414 (1948).

${ }^{74}$ It would appear that no difficulty will be encountered in the event that a note, otherwise negotiable, states that it is secured by a conditional sales contract or a chattel mortgage. $\$ 3-105$ (I) (d) scems to preserve negotiability there. The difficult situations will be those where the instrument itself reserves the security.

${ }^{75} \$ 3-105(\mathrm{r})(\mathrm{g})$.

${ }^{77}$ Similar in theory is $\$ 3-105(\mathrm{I})(\mathrm{f})$ by which a promise or order is declared not conditioned by the fact that it is limited to payment out of a particular fund if the instrument is issued by the government or a governmental agency. This, also, is new. 
In Section 3-105 appears an example of the type of draftsmanship which occurs in several places in the Code, wherein the legislation seems to deal with specific minutiae instead of adopting general guiding principles. The particular subsection is Section 3-105(I) (b), providing:

A promise or order otherwise unconditional is not made conditional by the fact that the instrument ... states its consideration, whether performed or promised, or the transaction which gave rise to the instrument, or that the promise or order is made or the instrument matures in accordance with or "as per" such transaction. ...

At the other extreme, displaying what is not permissible in a negotiable instrument, Section 3-105(2) declares:

A promise or order is not unconditional if the instrument (a) states that it is subject to or governed by any other agreement. . . .

No objection is directed to the results produced by these sections in applicable cases. A note which recites that it is given "as per" another agreement is not rendered uncertain by that recitation. The drafters were attempting to insure this result, thereby overcoming some contrary decisions under the Negotiable Instruments Law. ${ }^{78}$ The writer, however, doubts the desirability of legislating rules applicable to specific cases of this sort. Any number of combinations of words may raise the basic question whether the instrument is conditioned on another agreement or whether the other agreement is simply recited as an existing fact. The quoted words, " 'as per' such transaction," are examples, not rules. Why, therefore, should not those words be placed in the comment, illustrating what is meant by the clause, " $\mathrm{A}$ promise or order . . . is not made conditional by the fact that the instrument . . . states its consideration, whether performed or promised, or the transaction which gave rise to the instrument. .."?

While suggestions are being made concerning transmogrifying minutiae from statute to comments, one suggestion of a move in the other direction seems in order. Section 3-I07, defining money and rejecting the legal tender test in favor of the broader test of circulability in a given area, is explained by good comments, the last sentence of paragraph 3 of which seems to state a principle worthy of codification. That sentence is: "The amount payable under an instrument which expresses the sum in foreign money is determined by the current rate of exchange at the time of default." Money, like a French novel, frequently loses something in the translation, and a certain rule for measuring that loss (or gain) seems essential. The rule announced in the comment is the majority American rule, though there is authority to the contrary, ${ }^{79}$ taking other times for measuring the exchange rate. Unlike most comments appended to the Code sections, this statement does not serve to explain

\footnotetext{
;s Continental Bank \& Trust Co. v. Times Publishing Co., $x_{42}$ La. 209, 76 So. 6I2 (1917), noted 5 VA. L. Rev. 284 (I9I8) and 27 YALE L. J. 559 (I9I8).

${ }^{70}$ C. T. McCormick, Cases and Materials on the Law of Damages $\$ 49$ (1935); Notes, it A. L. R. 363 (I921), 33 A. L. R. 1285 (1924), 43 A. L. R. 520 (I926), 50 A. L. R. 1273 (1927), I05 A. L. R. 640 (1936) (superseding 80 A. L. R. 1374 (1932)).
} 
the basic statute. It gives a rule concerning which there is some difference of opinion in the authorities. In such a situation, codification of the rule would seem to be the only means for producing uniformity. At any event, the present position of this statement as a comment may constitute a danger spot so far as uniform construction of the Code is concerned.

In Section 3-109 of the Article appear several highly desirable changes in the law with respect to the requirement that a negotiable instrument must be payable at a definite time. Unless some certainty exists as to when the instrument is due, its value becomes uncertain. Furthermore, an obligor needs to know with some degree of certainty when his obligation will be due, so he can have the money ready to make payment. The holder must also know when maturity occurs, so he can take necessary steps to hold secondary parties in case of dishonor. An instrument payable on the death of a person fails to meet any of these reasons, yet under the present law, a note payable on the death of a person, or any other event certain to occur, is negotiable. $^{80}$ The Code wisely adopts a contrary position in Section 3 -rog(2)..$^{81}$

Equally difficult to justify is the rule adopted under the present statute that a note giving the holder an unlimited option to accelerate cannot be negotiable. ${ }^{82}$ The Code's provision with respect to acceleration provisions is:

An instrument is payable at a definite time if by its terms it is payable at a definite time subject to any acceleration. . . . ${ }^{83}$

A limitation on the power to accelerate is found, however, in Section I-208, imposing a requirement of good faith belief of the holder that the hazard of nonpayment is increased before he may elect to accelerate an instrument giving him the right so to do "at will" or "when he deems himself insecure." This approach, while having no previous statutory background, does accord with accepted principle. ${ }^{84}$

A further restriction on accelerating provisions may be contained in Section 3-II2(I)(d):

The negotiability of an instrument is not affected by ... a term authorizing a confession of judgment on the instrument if it is not paid when due....

The necessary negative inference ${ }^{85}$ is that a provision giving a power to confess ${ }^{85}$ Indeed, the official Comment 2 makes this more than an inference.

judgment at any time destroys negotiability. A person drafting a negotiable instru-

${ }^{80}$ See discussion in Joseph v. Catron, $x_{3}$ N. M. 202, 8r Pac. 439 (1905).

81 "An instrument which by its terms is otherwise payable only upon an act or event uncertain as to time of occurrence is not payable at a definite time even though the act or event has occurred."

${ }^{82}$ Puget Sound State Bank v. Washington Paving Co., 94 Wash. 504, 162 Pac. 870 (1917); Chafec, Acceleration Provisions in Time Paper, 32 Har. L. Rev. 747, 775 (1919).

${ }^{83} 53-\operatorname{Iog}(x)(c)$. Professor Chafee's learned discussion of acceleration provisions (supra note 82) would indicate that permitting "any acceleration" is too broad and that the accelcrating cvent should be connected with collection of the paper. The courts, however, do not seem to have followed the suggested lead of Professor Chafee in this regard. See Charlton v. Reed, 6r Iowa 166, 16 N. W. 64 (1883); Nickell v. Bradshaw, 94 Ore. 580, 183 Pac. 12 (1919).

- 'st See Manufacturers' Finance Acceptance Corp. v. Woods, 222 Ala. 329, 132 So. 61 I (I931), noted I7 VA. L. REv. 826 (I93I) (involving a clause in a chattel mortgage authorizing repossession when the mortgagee "deemed" himself insecure). 
ment must be careful, therefore, to restrict power to confess judgment so that it can be exercised only after the instrument becomes due. ${ }^{86}$

While extension of time of payment may be permitted without interfering with negotiability, ${ }^{87}$ a new provision may be found in Section 3 -II9(f) that:

The following rules apply to every instrument. ... Notwithstanding any term of the instrument, the holder may extend it only with the consent of the maker at the time of extension. Unless otherwise specified consent to extension authorizes a single extension for not longer than the original period.

This, too, accords with existing principles, ${ }^{88}$ but it does serve to clarify a doubtful point under existing statutes.

Section 3-1 I2 improves and clarifies the provisions of Negotiable Instruments Law Sections 5 and 6, particularly by providing that a promise to give additional collateral on demand does not interfere with negotiability. ${ }^{89}$ Thereby a conflict of authority under existing legislation is ended. ${ }^{90}$

Another new provision is Section $3-\operatorname{II2}(\mathrm{I})(\mathrm{f})$ :

The negotiability of an instrument is not affected by ... a term in a draft providing that the payee by indorsing or cashing it acknowledges full satisfaction of an obligation of the maker or drawer.

In this regard, it is suggested that the Code contains a rider which will serve to upset a principle of the law of contracts which has been settled (but wrongly) for many years. The particular provision is Section 3-702(3):

Where a check or similar payment instrument provides that it is in full satisfaction of an obligation the payee satisfies the underlying obligation by negotiating the instrument or obtaining its payment unless he establishes that the original obligor has taken unconscionable advantage in the circumstances or unless it is the drawer who has initiated collection on behalf of the payee.

At last, by this statute, a man may pay a debt by paying a lesser sum than is due; thereby shaking the foundations of an old rule of contracts. ${ }^{91}$ The rule has been criticized by many able scholars, ${ }^{92}$ so this Section will be welcome. ${ }^{93}$ A similar

${ }^{86}$ This, of course, is also true under Negotiable Instruments Law $\$ 5(2)$.

${ }^{87} 53-\log (\mathrm{I})(\mathrm{d})$.

${ }^{88}$ Pugh v. Dawson, 95 Cal. App. 505, 273 Pac. 39 (r929); Security National Bank of Sioux City v. Gunderson, 52 S. D. 25,216 N. W. 595 (1927).

${ }^{80} \$_{3-1} I_{2}(\mathrm{I})(\mathrm{c})$.

${ }^{80}$ Holliday State Bank v. Hoffman, 85 Kan. 7I, II6 Pac. 239 (IgII); Finley v. Smith, I65 Ky. 445, I77 S. W. 262 (I9I5); First National Bank v. Blackman, 249 N. Y. 322,164 N. E. II3 (I928).

${ }^{0 x}$ In Ludington v. Bell, 77 N. Y. 138, 143, 33 Am. Rep. 6or (1879) the court says: "The doctrine that payment by the debtor of a less sum than the whole amount of the debt will not extinguish the debt, although the creditor expressly agree to receive it in full and give a receipt or writing to that effect, is well established by abundant authority. But while the correctness of the rule stated may be conceded, it should be borne in mind that it rests mainly upon a want of consideration for the promise made."

${ }^{02}$ E.g., Merton L. Ferson, The Rational Basis of Contracts and Rezated Problems in Legaz ANaryss I53 et seq. (1949).

${ }^{03}$ While clearly the sections cited will cover most of the cases in which the problems arise, i.e., payment by check, there would seem to be a danger spot of uncertainty hidden in the two sections 
policy will be found expressed with respect to the consideration section of the Article. $^{94}$

Another example of adroit handling of a snarled legal problem is demonstrated by Section $3-116^{95}$ as coupled with Section $3-4070^{90}$ These two sections simplify and correlate materials now covered in Negotiable Instruments Law Sections I3, I4, I5, and $\mathbf{1 2 4}$, and remove certain undesirable provisions of the present legislation. The rule of Negotiable Instruments Law Section I5, by which non-delivery of incomplete paper is a real defense, is reversed. Thereby harmony is produced between that situation and the situation in which paper is filled in by an agent in excess of the authority possessed by him. ${ }^{97}$ It is worthy of notice at this point that the protection

granted to due course holders by these and other sections will be accorded to payees (who meet the requirements of due course holding) by the Code. ${ }^{08}$ Finally, with respect to material alteration, the Code makes clear that which is not clear under Negotiable Instruments Law Section 124, that liability is not discharged either (I) by alteration by a stranger or (2) by innocent alteration.

Protection granted to due course holders by these sections is available, likewise, to drawee banks which pay out on altered checks. Section 450 r provides:

... (2) A bank that in good faith makes payment to a holder may charge the indicated account of its customer

(a) according to the original tenor of his altered item; or

(b) according to the tenor of his completed item, even though the bank knew it was incomplete when delivered.

quoted. $\$ 3-702(3)$ applies to a "check or similar payment instrument." What is a "similar payment instrument"? Further, in $\$_{3-I I 2(I)(f)}$ there seems to lie a basic inconsistency in that the statement is that negotiability "is not affected by a term in a draft providing that the payee by indorsing or cashing it acknowledges full satisfaction of an obligation of the maker or drawer." Doesn't the word, "maker," usually apply only to one who executes a note, thus leaving the inference that a note may also be negotiable even if it contains a term like that authorized for drafts?

os $\$ 3-408$, Comment 2.

O5 "(I) When a paper whose contents at the time of signing show that it is intended to become an instrument is signed while still incomplete in any necessary respect it cannot be enforced until completed, but when it is completed in accordance with authority given it is valid as completed.

"(2) If the completion is unauthorized the rules as to material alteration apply (Section 3-407), even though the paper was not delivered by the maker or drawer; but the burden of establishing that any completion is unauthorized is on the party so asserting."

Do "(I) Any alteration of an instrument is material which changes the contract of any party thercto in any respect, including any such change in

"(a) the number or relations of the parties; or

"(b) an incomplete instrument, by completing it otherwise than as authorized; or

"(c) the writing as signed, by adding to it or by removing any part of it.

"(2) As against any person other than a subsequent holder in due course

"(a) alteration by the holder which is both fraudulent and material discharges any party whose contract is thereby changed, unless that party assents or is precluded from asserting the defense;

"(b) no other alteration discharges any party and the instrument may be enforced according to its original tenor, or as to incomplete instruments according to the authority given.

"(3) A subsequent holder in due course may in all cases enforce the instrument according to its original tenor, and when an incomplete instrument has been completed, before he takes, he may cnforce it as completed."

${ }^{27}$ Negotiable Instrunients LAW $\$ 14$.

${ }^{03} \$ 3-302(2)$ : "A payee may be a holder in due course." For authorities illustrating the current doubt on this point, see Annotations, 142 A. L. R. 489 (1943) and I69 A. L. R. I455 (1947). 
Where payment by the bank is made to a due course holder, the same protection will be given the bank by application of Section $4-50 \% .^{99}$

Observe that by Section $4-501$ (2) (b), just quoted, a drawee bank may charge the drawer's account on paper which has been completed, even though the bank knew that it was delivered in an incomplete state. A reference to Section 3-304(5)(d) ${ }^{100}$ will show that the same protection is granted to a holder in due course. In short, a holder who knows of no limitation on the authority of an agent to whom a negotiable instrument has been entrusted for completion may rely on the ostensible authority of that agent to complete the paper, and the taker may be a due course holder, even though he sees the agent complete the paper. This was the rule which prevailed at common law. ${ }^{101}$ The Negotiable Instruments Law codifies a contrary view, by requiring that the holder in due course take complete and regular paper, ${ }^{102}$ and by the last sentence of Negotiable Instruments Law Section I4: "But if any instrument after completion is negotiated to a holder in due course," it is valid for all purposes in his hands. ${ }^{103}$ This change seems desirable.

Several improvements in existing codification are found in Section 3-20r, foremost of which is the provision that a reacquirer who had notice of a defense cannot, by shooting the instrument through a holder in due course, improve his position. ${ }^{104}$ While this was the common law rule, ${ }^{105}$ the relevant provision of the present statute, ${ }^{100}$ which seems to deny the privilege of claiming through a holder in due course only to persons who had a part in the fraud or illegality, has been held to entitle a reacquirer who merely had notice of the wrong to claim through a due course holder and thereby improve his position. ${ }^{107}$

One illustration annexed to demonstrate the operation of this Section seems misleading. ${ }^{108}$ This illustration appears to mean that a holder in due course who, after

00 "To prevent unjust enrichment, a bank which has paid a customer's item which it may not charge in full to his account may in an action ... (b) against the drawer, maker or acceptor recover any amount which would have been due from him on the item if payment had been refused."

100 "Knowledge of the following facts does not of itself give the purchaser notice of a defense or claim ... that an incomplete instrument has been completed, unless the purchaser has notice of any improper completion."

${ }_{101}$ Fullerton v. Sturges, 4 Ohio St. 529 (1855); Vander Ploeg v. Van Zuuk, 135 Iowa 350, Ir2 N. W. 807 (1907).

102 Negotiable Instruments Law $\$ 52$.

${ }^{103}$ (Italics supplied.) Bronson v. Stetson, 252 Mich. 6, 232 N. W. 74 I (1930), exemplifies the cases holding that these Negotiable Instruments Law sections adopt the English rule, contrary to the common law rule prevailing in America.

104 $\$_{3-201}(\mathrm{I})$ : "Transfer of an instrument vests in the transferee such rights as the transferor has therein, except that a transferee who has himself been a party to any fraud or illegality affecting the instrument or who as a prior holder had notice of a defense or claim against it cannot improve his position by taking from a later holder in due course."

${ }^{105}$ Dollarhide v. Hopkins, 72 Ill. App. 509 (I897).

${ }^{200}$ Negottable Instruments Law $\$ 58:$ ". . . But a holder who derives his title through a holder in due course, and who is not himself a party to any fraud or illegality affecting the instrument, has all the rights of such former holder in respect of all parties prior to the latter."

${ }^{207}$ Horan v. Mason, I41 App. Div. 89, 125 N. Y. Supp. 668 (2d Dep't 19ro).

${ }^{108}$ Comment 3 (d) (Paraphrased): $A$ induces $M$ by fraud to make an instrument payable to $A$; $A$ negotiates to $B$, who had no notice of the fraud when he first acquired the instrument, but learned of it while he was a holder and with such knowledge negotiated to $C$, who negotiates it back to $B$. $B$ does not succeed to $C$ 's rights as a holder in due course, and his position is not improved by the negotiation and repurchase. 
learning of a defense, negotiates to another party from whom he reacquires, may not resume his original status of due course holding. There is no reason why this should be so, since no harm is caused to the maker or drawer by allowing resumption of the prior position. This is not a case where the holder, by reacquisition, "improves" his position.

One source of annoyance under the Negotiable Instruments Law has been the restrictive indorsement, one type of which has previously been discussed. ${ }^{100}$ The contribution of the Code is a clarification of the effect of specific types of indorsements, without use of a generic classification, "restrictive." If the indorsement is, "Pay A only," A may nonetheless transfer, but any subsequent taker, except a bank, has notice of the limitation on A's right to transfer and is subject to the indorser's rights. ${ }^{110}$ An indorsement, "Pay $A$ for my use," is treated just like an indorsement, "Pay A in trust for X (someone other than the indorser)," which has already been discussed. However, a blank indorsement, "For Deposit," or "For Collection," has the effect of restraining transfer of the instrument to the process of collecting. Therefore, any subsequent taker except a bank ${ }^{111}$ has notice of the indorser's rights ${ }^{112}$ and is consequently not a holder in due course.

While the approach taken in these specific situations is commendable, some challenge can be directed to the conception of notice which underlies them. ${ }^{113}$ The point at issue is that a taker may have notice of a claim of a beneficiary of a trust, or even of a transfer which was a voidable preference in bankruptcy or insolvency, ${ }^{114}$ and thereby be rendered subject to defenses totally disconnected from either the breach of trust or the voidable preference. ${ }^{115}$ The threatened difficulty exists under the present statute, ${ }^{116}$ and possibly no better solution is available.

One element of the notice section, however, deserves an affirmative word of praise. Under existing statutes, authorities do not agree whether a taker of a series of notes after default on one of the series may be a due course holder as to the balance. ${ }^{117}$ The Code treats this situation just as if it were a breach of an instalment of an instalment note, and therefore a taker of such a series after a breach cannot be a due course holder. ${ }^{118}$

${ }^{100}$ See note 21 et seq., supra.

$111 \$ 4-208(3)$.

${ }^{120} \$ 3-205$.

$112 \$ 3-304(3) ; \$ 3-206$.

${ }^{113}$ Palmer, Negotiable Instruments under the Uniform Commercial Code, 48 Mrch. L. Rev. 255, 29 I (1950).

$114 \$ 3-304(2)(a)$.

${ }^{215}$ Suppose an instrument, before issue, is changed so that the amount is increased as follows \$500. The instrument is transferred to a holder, and thereafter the payee fails to deliver to the maker the consideration for which the instrument was delivered. It would appear that, while the change in amount wasn't an alteration, hence not a defense, the taker would nonetheless be subject to the defense of failure of consideration. $(\$ 3-304(\mathrm{I})(\mathrm{a})$.)

${ }_{110}$ Palmer, supra note 113 .

117 Hobart M. Cable Co. v. Bruce, 135 Okla. 170, 274 Pac. 665 (1929); Morgan v. Farmington Coal \& Coke Co., 97 W. Va. 83, 124 S. E. 591 (1924) (taker may be a due course holder); Beaslcy Hardware Co. v. Stevens, 42 Ga. App. I14, 155 S. E. 67 (1930) (taker may not be a due course holder); Notes, I5 Minn. L. Rev. 585 (I93I); 44 Harv. L. Rev. 464 (I93I).

$118 \$ 3-304(4)(\mathrm{a}), 3-304(5)(\mathrm{f})$. 
The definition of value in Section $3-303^{119}$ accords with the currently prevailing rules. An executory promise, other than one which is irrevocable or embodied in a negotiable instrument, is not value. This same rule applies to bank credit, which is not value by the current weight of American authority ${ }^{120}$ or by the provisions of Article IV of the Code, Sections 4-2II $\mathrm{I}^{121}$ and 4-2ז2.129 Once the credit has been withdrawn, of course, the bank becomes a holder for value, but at present there is doubt as to when the credit may be said to have been withdrawn. The Code adopts the so-called "first-money-in-first-money-out theory," ${ }^{223}$ which is the currently prevailing rule. ${ }^{124}$

Section 3-405 introduces an entirely new concept with respect to paper payable to imposters, and "fictitious payees." That Section provides:

(x) With respect to a holder in due course or a person paying the instrument in good faith an indorsement is effective when made in the name of the specified payee by any of the following persons, or their agents or confederates:

(a) an impostor who through the mails or otherwise has induced the maker or drawer to issue the instrument to him or his confederate in the name of the payee;

(b) a person signing as or on behalf of a drawer who intends the payee to have no interest in the instrument;

(c) an agent or employee of the drawer who has supplied him with the name of the payee intending the latter to have no such interest.

(2) Nothing in this section shall affect the criminal or civil liability of the person so indorsing.

The concept introduced is that in none of the listed situations does the paper become bearer paper as under Negotiable Instruments Law Section 9(3). ${ }^{125}$ However, the indorsement by the impostor or by his confederate is "effective," which means that title to the instrument can pass by such indorsement. The net result, then, is the same as the result under the present statute, except that subparagraph (r)(c) of Section

110 "A holder takes for value:

"(a) to the extent that the agreed consideration has been performed or that he acquires a security interest in or a lien on the instrument otherwise than by legal process; or

"(b) when he takes the instrument in payment of or as security for an antecedent claim against any person whether or not the claim is due; or

"(c) when he gives a negotiable instrument for it or makes an irrevocable commitment to a third person."

${ }^{120}$ Citizens' State Bank v. Cowles, 180 N. Y. 346,73 N. E. 33 (1905); Central Savings Bank \& Trust Co. v. Wachman, 221 Mich. 512, I9I N. W. 5 (1922).

232 "(I) A bank has a security interest in an item, any accompanying documents or the proceeds of either (a) in case of an item deposited in a checking account, to the extent to which credit given for the item has been withdrawn or applied. ...."

122 "For purposes of determining its status as a holder in due course, the bank has given value to the extent that it has a security interest in an item and a bank which takes a negotiable instrument before maturity for deposit in a checking account in good faith and without notice of any claim or defense is a holder in due course to the extent that credit given for the instrument is withdrawn or applied, whether before or after maturity, before the bank has had a reasonable opportunity, after having received notice of a claim or defense, to charge back the amount of the interest purchased or credit given."

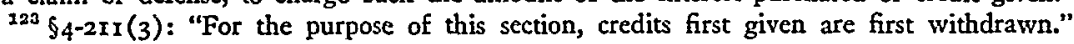

124 Britron, Bills and Notes $\$ 97$ (I943).

${ }^{125}$ Snyder v. Corn Exchange National Bank, 22r Pa. 599, 79 Atl. 876 (1908). 
$3-405$ codifies a view contrary to the present weight of authority. ${ }^{126}$ By the present view, if an agent merely supplies the names of person to whom checks are drawn by another, in as much as the actual drawer of the checks intends the designated payee to have an interest in the paper, a signature by the furnisher of the name is a forgery; under the Code, however, that signature is effective.

Section $3-406^{127}$ codifies and expands the rule of Young v. Grote, ${ }^{128}$ recognizing a duty owed by a drawer both to subsequent takers and to the drawee to draw the instrument so as not to facilitate material alteration or forgery. Furthermore, an additional duty rests on the drawer of checks to examine his returned vouchers to determine whether there has been a forgery or a material alteration. ${ }^{120}$ The penalty for the drawer's failure to use reasonable care is either ( $I$ ) liability for damages caused to the bank, which would be the amount of money which the bank could have recovered from the forger or alterer but for the failure to give notice, ${ }^{120 n}$ or (2) in the event of a delay for more than 90 days, an estoppel against the drawer's denying liability at all on either the particular instrument or on subsequent instruments forged or altered by the same party. Statutes of similar nature exist in most states today. ${ }^{130}$

With respect to checks, drafts, and notes on which the signature of the drawer or maker is forged, the doctrine of Price $v . N_{e a l}{ }^{131}$ is retained. ${ }^{132}$ The effect of this is that if payment is made by the maker or drawee on such an instrument to a holder in due course, the money so paid may not be recovered. And, by the same principle,

${ }^{120}$ National Union Fire Ins. Co. v. Mellon National Bank, $276 \mathrm{~Pa}, 212$, 119 Atl. 910 (I923).

127 "Any person who by his negligence contributes to a material alteration of the instrument or to the making of an unauthorized signature is precluded from asserting the alteration or lack of authority against a holder in due course or a drawee who pays the instrument in good faith."

${ }^{128} 4$ Bing. 253, 130 Eng. Rep. 764 (C. P. 1827 ).

120 4-506: "(I) Where a bank sends to its customer a statement of account accompanied by items paid in good faith in support of the debit entries or sends notice to him that such a statement is ready for delivery

"(a) the customer must exercise reasonable care to examine the statement and items to discover his unauthorized signature or any alteration and must notify the bank promptly after the discovery thereof; he is liable to the bank for any loss suffered by it in respect to his items resulting from his failure to do so; and

"(b) except as provided in subsection (2) a customer who does not within ninety days discover and report his unauthorized signature or any material alteration on the face of any such item is precluded from asserting against the bank both such unauthorized signature or alteration and an unauthorized signature or alteration by the same person on an item paid in good faith by the bank subsequent to the sending of the first item or notice to the customer and before receipt of notification form the customer of any such signature or alteration.

"(2) A customer who has not for good cause examined such statement and items may within thirty days after such cause ceases to operate demand recredit or repayment for the amounts paid on items materially altered or bearing his unauthorized signature."

${ }^{1202}$ As under the present statute and common law decisions, as typified in First National Bank $v$. Allen, 100 Ala. 476, 14 So. 335 (1893).

${ }^{130} \$ 4-205$, Comment I (Spring, I950 draft).

1313 Burr. 1354, 97 Eng. Rep. 87 (K. B. 1762).

${ }^{132} \$ 3-418$ : "Except for recovery of bank payments as provided in the Article on Bank Deposits and Collections (Article 4) and except for liability for breach of warranty on presentment under the preceding section, payment or acceptance of any instrument is final in favor of a holder in due course, and so far as concerns a stop order or the sufficiency of the drawer's accaunt is final in favor of any holdcr." 
money paid by a drawee when the drawer's account is insufficient may not be recovered from the holder paid, ${ }^{133}$ even though the holder is not a holder in due course.

The basis for retention of Price v. Neal is the need for a point of final settlement, either after a payment or after an acceptance. Under existing statutes and agreement forms drawn up by banks, the determination of this point of final settlement may become difficult. Where money is paid over the counter to the presenter, no difficulty exists; the payment over is final. Where the transaction takes the form of credit to the account of a depositor, however, under existing law no uniformity can be spelled out, largely because of diversified banking agreements. In many cases, the drawee's bookkeeping entries crediting the depositor's account were held irrevocable. ${ }^{134}$ Under Article Four of the Code, recognition is given to the custom of banks to use deferred posting, and the bank will have a right to charge back, within a prescribed time limit. The Code provides:

(x) Unless an earlier time is agreed, where an authorized settlement for a demand item (other than a documentary draft) payable by [at] or through a bank, presented by mail or through a clearing house has been made before midnight of the day of presentment the payor bank may revoke the settlement and recover any payment if before its midnight deadline it

(a) returns the item; or

(b) sends written notice of dishonor or non-payment if the item is held for protest or is otherwise unavailable for return.

(2) If an item is presented to a payor bank for credit on its books it may return such item or send notice of dishonor and may revoke any credit given or recover the amount thereof withdrawn by its customer, if it acts within the time limits and in the manner specified in the preceding subsection. ${ }^{135}$

This, then, gives the bank a period after settlement with the depositor during which the credit may be removed by charging back, thereby permitting the bank to prevent loss to itself.

As a common law matter, money could be recovered by the paying drawee from a presenter who acted in bad faith ${ }^{136}$ or negligently. ${ }^{137}$ These, then, were exceptions imposed on the operation of Price $v$. Neal. Under the Code, however, negligence of the recipient of the money will not permit the drawee to recover the money from him. ${ }^{138}$ The person presenting the instrument for payment or acceptance warrants, however, that "he has no knowledge that the signature of the maker or drawer is unauthorized"; ${ }^{130}$ consequently, if he does have such knowledge, the money paid him may be recovered.

${ }^{133}$ Accord, under present law, Riverside Bank v. First National Bank of Shenandoah, 74 Fed. 276 (2d Cir. 1896 ).

${ }^{134}$ Cohen v. First National Bank, 22 Ariz. 394, I98 Pac. 122 (I921); Schutte v. Citizens' Bank of Hanesville, 3 La. App. 546 (1926); First National Bank v. Mammoth Coal Co., I94 Ky. 580, 240 S. W. 78 (1922); Hay v. First National Bank, 244 Ill. App. 286 (1927).

130 " $\$ 4-401$.

${ }_{130}$ Banca Commerciale Italiana Trust Co. v. Clarkson, 274 N. Y. 69, 8 N. E.2d 28 I (1937).

${ }^{137}$ Ellis \& Morton v. Ohio Life Insurance \& Trust Co., 4 Ohio St. 628, 64 Am. Dec. 6Io (I855).

138 \$3-41 8 , Comment 4 . ${ }^{139} \$ 3-4 I 7(\mathrm{I})(\mathrm{c})$. 
Here, again, is a new concept under the Code-that persons presenting an instrument for payment or acceptance make certain warranties. ${ }^{140}$ This is a departure from the Negotiable Instruments Law, in as much as the warranties listed in that law ${ }^{141}$ are made by negotiation, and it is generally held that presentment to the drawee for payment is not a negotiation. ${ }^{142}$

To put this in terms of an example, under existing statutes, money paid to a person in possession of an instrument under a forged indorsement could be recovered by the payor from the person so paid under principles of restitution and unjust enrichment, ${ }^{143}$ while under the Code the recovery will be based on a warranty given by the person presenting for payment. ${ }^{144}$ Similarly under the Code, a presenter warrants that there has been no material alteration of the document presented. ${ }^{145}$ Excepted from this warranty is the holder in due course who took the instrument accepted after the alteration. Consequently, money paid on an altered instrument may be recovered in most instances, as was true under the common law cases prior to the Negotiable Instruments Law. ${ }^{146}$

Section 3-4IO introduces an innovation in that the drawee's acceptance must now be written on the draft. This means that virtual and collateral acceptances ${ }^{147}$ are no longer possible; further, the drawee's delay or refusal to return a draft does not operate as an acceptance, ${ }^{148}$ but the drawee may be liable for conversion. ${ }^{140}$ In the case of a payor bank, however, it is provided that:

Unless the customer of the depositary bank has broken a presentment warranty (Section 4-2ro) he may recover from the payor bank

$140 \$ \$ 3-4 I 7$ and $4-210$.

141 NegotTABLe INSTRUMENTS LAw $\$ \$ 65$ and 66.

${ }^{242}$ State Planters Bank \& Trust Co. of Richmond, Va. v. The Fifth-Third Union Trust Co., of Cincinnati, Ohio, 56 Ohio App. 309, 10 N. E.2d 935 (1937).

${ }^{143}$ State Planters Bank \& Trust Co. of Richmond, Va. v. The Fifth-Third Union Trust Co., of Cincinnati, Ohio, supra note r42; Canal Bank v. Bank of Albany, I Hill 287 (N. Y. $184 x$ ).

${ }^{144} \$ 3-417$. "(I) Unless otherwise agreed any person who obtains payment or acceptance and any prior transferor by indorsement and for consideration warrants to a party who pays or accepts in good faith

"(a) that he has a good title to the instrument or is authorized to obtain payment or acceptance on behalf of one who has a good title;

"(b) that he has now (sic) knowledge of any effective direction to stop payment; and

"(c) that the instrument has not been materially altered, and that he has no knowledge that the signature of the maker or drawer is unauthorized, except that such warranties are not given by a holder in due course who has taken the instrument accepted after such alteration or signature. This exception applies even though a draft has been accepted 'payable as originally drawn' or in equivalent terms. . . ."

$145 \$ 3-417(1)(c)$, quoted supra note 144 .

${ }^{148}$ Marine National Bank v. National City Bank, 59 N. Y. 67, 17 Am. Rep. 305 (1874).

147 Negotiable Instruments LAW $\$ \$ 34$ and 135 .

${ }^{148}$ As under Negotiable INSTRUMents Law $\$ 137$.

149 \$319: "(I) An instrument is converted when

"(a) a drawee to whom it is delivered for acceptance refuses to return it on demand; or

"(b) any person to whom it is delivered for payment refuses on demand cither to pay or to return it; or

"(c) it is paid on a forged indorsement."

Subparagraph $\mathrm{I}(\mathrm{c})$ is new, codifying present case law. Blacker \& Shepard Co. v. Granite Trust Co., 284 Mass. 9,187 N. E. 53 (1933). 
(a) the amount of a demand item other than a documentary draft presented by mail or through a clearing house whether properly payable or not if the payor bank [either retains it beyond midnight of the banking day of receipt without settling therefor or having settled on that day] does not return the item or send notice of dishonor until after its midnight deadline; or

(b) the amount of any other properly payable item presented to it if the payor bank within the time allowed for acceptance or payment of that item neither settles for it nor returns it and any accompanying documents. ${ }^{150}$

This, then, is a retention of Negatiable Instruments Law Section I37 so far as it pertains to banks. This provision seems to reflect the underlying thesis of the Bank Deposits and Collections Article that expeditious handling of all items is a primary obligation of depositary, collecting, and payor banks.

The Bank Deposits and Collections Article's very existence is an innovation, since there is no previous uniform legislation sponsored by the National Conference of Commissioners on Uniform State Laws. The Bank Collection Code and Model Deferred Posting Statutes, sponsored by the American Bankers Association, have been widely adopted, however.

A detailed analysis of Article 4 of the Code is not possible within the limits of this article; however, its operation has been ably discussed elsewhere. ${ }^{151}$ While there have been many changes in the Article since that study was written, in the main that discussion is an accurate treatment of the Article in its present form.

The Article sets forth certain prescribed methods of dealing with collection paper. Other practices are listed which are not permissible. ${ }^{152}$ These rules are so drafted as to minimize the risk of loss through improper handling or bank failure during the collection process. While it is not practicable to review here all of the provisions of the Article, attention is invited to one section:

(I) Notwithstanding Section I-ro7 the rights and obligations provided in this Article may be waived or modified by agreement except that no agreement can

(a) limit a bank's liability for its own negligence or lack of good faith; or

(b) limit a collecting bank's liability for authorization or ratification of a remittance in the form of a payor bank's primary obligation; or

(c) extend a time limit fixed by this Article except as otherwise provided in the following subsections; or

(d) limit a bank's obligation on written orders to stop payment; or

(e) limit the measure of damages for improper handling. . ..$^{153}$

${ }^{200} \$ 4-403$.

161 Note, 50 Col. L. Rev. 802 (1950).

${ }^{162}$ One somewhat dubious method of handling authorized by the Article is exemplified in $\$ 4-204$ (2) ("Sending an item direct to a payor bank is not improper handling. . . ."). An illustration of restrictions on methods of dealing with collection items is $\$ 4-205$ (" ( $I$ ) Where a bank has received an item under instructions to collect and remit or to pay and remit, remittance by its own cashier's check, certificate of deposit or other primary obligation is improper unless authorized or ratified by the bank's transferor. If the bank suspends payments any officer or director who has authorized such a remittance with knowledge that it was improper becomes liable as a surety for the bank to all prior parties for the amount. . . . (3) If by its midnight deadline a collecting bank fails to return an improper remittance or send it for collection, the bank becomes liable as if it had received final payment.").

1 153 $\$ 4-103$. 
Authorities presently differ on the effectiveness of exculpatory clauses inserted by banks in their stop payment orders and other banking agreements. ${ }^{154}$ The Code narrowly restricts the power of banks to limit their liability. One major limitation on the liability of the bank is found, however, in the Code's provision that:

A bank which does not return an item to its customer within a reasonable time after receiving it for collection must use [diligence and] good faith in ... (b) selecting intermediary banks or agents but is otherwise not liable for the insolvency of or for improper handling by any intermediary other than its own branch or employee. . . ${ }^{165}$

This is the so-called Massachusetts rule of non-liability for correspondents, and it will amount to a restriction on the liability of banks taking documents for collection.

The Article on Bank Deposits and Collections and the Article on Commercial Paper are written in an effort to state basic principles in as simple a form as possible. This achievement of simplicity is possibly best illustrated by the sections of the Code dealing with presentment, notice of dishonor, and protest. It is worthy of note that in the Negotiable Instruments Law more than one-third of the Ig6 sections apply to these matters. ${ }^{156}$ The Code covers the same material in eleven sections. There have been modifications in the requirements for presentment, notice, and protest, all directed toward simplifying the process. For example, the method of presentment is divested of any requirement that the instrument be exhibited, ${ }^{157}$ unless the person to whom presentment is made requests such exhibition. ${ }^{158}$ In short, technical objections to the presentment must be made by the person to whom presentment is made, or any demand for payment or acceptance is sufficient.

The development of uncomplicated procedures for dealing with commercial paper will certainly serve the needs and interests of commercial people. And this, it would seem, is the ultimate test which the Code must meet-will it foster an expedient solution to commercial problems? It can only do so if it is written with a full appreciation of those problems and of the methods used by people in commerce to cope with them. Reference to one final innovation (though there are many not covered in this discussion) will serve, perhaps, to demonstrate that the third and fourth Articles of the Code were written with an eye toward what commercial men do. The modification here alluded to is, briefly stated, that presentment for payment and notice of dishonor are not required in order to create liability on the part of the indorsers of a promissory note, unless they add to their indorsement, "Presentment required." "T59 This is a fundamental departure from existing law. ${ }^{100}$ Why should such a fundamental change be made? The reason set forth in the Comments is, in effect, that almost all notes have clauses in them waiving present-

\footnotetext{
${ }^{164}$ See Leary, Some Clarifications in the Law of Commercial Paper Under the Proposed Uniform Commercial Code, 97 U. of PA. L. Rev. 354, 366 (1949).

$165 \$_{4-202 .}$

166 Ogden, Negotiable Instruments 384 (1947).

$167 \$ \$ 3-504$ and $4-303$.

$168 \$ 3-505$.

269 \$3-501.

${ }^{100}$ Negotiable Instrumients Law $\$ \$ 66,70$, and 89.
} 
ment and notice anyway. At first blush, this reminds one of the story of the traveler who narrowly escaped hurtling his car over an unmarked precipice. He asked a native why no sign had been erected to warn of the cliff, and the native's reply was that there had been a sign on the spot for many years, but nobody drove over the brink, so the sign was removed. In short, this section of the Code would appear to deprive all indorsers of the protection of notice, merely because most indorsers did not use the protection anyway. So approached, the change would seem to promise only an undesirable trap for the unwary.

But, observed from the point of view of the long-range purpose of the Code, an instrument to govern commercial dealing, this change becomes defensible, and, indeed, commendable. The Code is written to govern commercial dealings; consequently, it must reflect all that is customary in such dealings, or, like Lord Holt's blunder in Clerke v. Martin, ${ }^{161}$ the Code will be foredoomed to failure. The final suggestion is here made, therefore, that Articles 3 and 4 of the Code have been written with a full realization of the best of modern commercial understanding, and it consequently may be expected to embody a working tool by which commercial problems may be solved.

${ }^{101} 2$ Ld. Raym. 757, 92 Eng. Rep. 6 (K. B. 1702). Lord Holt held, contrary to the established custom of merchants, that a promissory note was not a negotiable instrument. His decision could last for only two years, when it was changed by statute. 